\title{
EKSPLORASI Actinomycetes SEBAGAI KANDIDAT ANTIBAKTERI PATOGEN YANG RESISTEN DARI RHIZOSFER TUMBUHAN LEDA (Eucalyptus deglupta Blume.) DI TAMAN NASIONAL LORE LINDU, INDONESIA
}

\section{Exploration Of Actinomycetes As A Pathogen Antibacterial Candidate From Rhizosphere Of Leda (Eucalyptus deglupta Blume.) At Lore Lindu National Park, Indonesia}

\author{
Muhammad Alwi ${ }^{1)}$ Suharjono Suharjono ${ }^{2)}$ Tri Ardyati $^{2)}$ dan Subandi Subandi ${ }^{3)}$ \\ 1) Jurusan Biologi Fakultas Matematika dan IImu Pengetahuan Alam Universitas Tadulako, Palu \\ 2) Jurusan Biologi Fakultas Matematika dan IImu Pengetahuan Alam Universitas Brawijaya, Malang \\ 3) Jurusan Kimia Fakultas Matematika dan IImu Pengetahuan Alam Universitas Negeri Malang
}

Actinomycet

es,

Eucalyptus

deglupta

Blume., and

pathogenic

antibacterial

Kata Kunci:
Actinomycet
es,
Eucalyptus
deglupta
Blume., dan
antibakteri
pathogen

Kata Kunci: Actinomycet

$$
\text { es, }
$$
deglupta Blume., dan pathogen

\begin{abstract}
Actinomycetes that live in the rhizosphere of the Leda plant (Eucalyptus deglupta Blume.) Have the potential to produce pathogenic antibacterial compounds in humans. The ecosystems thought to be inhabited by Actinomycetes that produce pathogenic antibacterial compounds in humans is the rhizosphere of Leda endemic plant in the Lore Lindu National Park, Central Sulawesi. The purpose of this study was to isolate various isolates of Leda plant rhizosphere Actinomycetes in TNLL as a producer of pathogenic antibacterial compounds in humans. This research is divided into several stages. The first stage was sampling, isolation, and screening of Actinomycetes producing human pathogenic antibacterial compounds. Rhizosphere soil samples were taken by purposive sampling method combined with the quadrant method by measuring various environmental factors. The second stage is a selection to analyze the potential and efficacy of Actinomycetes isolates as producing antibacterial compounds against pathogenic bacteria in humans.

The results showed that the condition of Leda plant vegetation in the Anaso-Rorekatimbu area was generally the same for each spot and supported the presence of Actinomycetes. The density of Actinomycetes is relatively the same for each spot. As many as 15 isolates were isolated from the Leda rhizosphere of Actinomycetes. Based on spore morphological and biochemical characterization, the 15 isolates were included in the Genus Streptomyces. Actinomycetes isolates L213, L433, and L411 were the most potent isolates and had broad-spectrum inhibition, because they were able to inhibit the four test bacteria S. aureus, MRSA, V. cholera, and EPEC.
\end{abstract}

\section{ABSTRAK}

Actinomycetes yang hidup di daerah rhizosfer tumbuhan Leda (Eucalyptus deglupta Blume.) mempunyai potensi menghasilkan senyawa antibakteri patogen pada manusia. Salah satu ekosistem yang diduga di huni oleh Actinomycetes penghasil senyawa antibakteri patogen pada manusia adalah rhizosfer tumbuhan khas Leda yang ada di kawasan Taman Nasional Lore Lindu, Sulawesi Tengah. Tujuan penelitian ini adalah mengisolasi berbagai isolat Actinomycetes rhizosfer tumbuhan Leda di TNLL sebagai penghasil senyawa antibakteri patogen pada manusia. Penelitian ini dibagi beberapa tahapan. Tahap pertama sampling, isolasi, dan skrining Actinomycetes penghasil senyawa antibakteri patogen manusia. Sampel tanah rhizosfer diambil dengan metode purposive sampling yang dipadukan dengan metode kuadran dengan mengukur berbagai faktor lingkungan. Tahap kedua merupakan seleksi untuk menganalisis potensi dan efikasi isolat Actinomycetes sebagai penghasil senyawa antibakteri terhadap bakteri patogen pada manusia.

Hasil penelitian menunjukkan bahwa kondisi tegakan tumbuhan Leda di daerah AnasoRorekatimbu pada umumnya adalah sama untuk setiap spot serta mendukung keberadaan Actinomycetes. Densitas Actinomycetes relatif sama untuk setiap spot. Actinomycetes rhizosfer tumbuhan Leda yang berhasil diisolasi sebanyak 15 isolat. Berdasarkan karakterisasi morfologi spora dan biokimia, maka ke-15 isolat ini termasuk kedalam Genus Streptomyces. Isolat Actinomycetes L213, L433, dan L411 merupakan isolat yang paling potensial dan memiliki daya hambat spektrum luas, karena mampu menghambat keempat bakteri uji $S$. aureus, MRSA, $V$. cholera, dan EPEC. 


\section{PENDAHULUAN}

Peningkatan kasus penyakit infeksi dan makin resistennya mikroba patogen terhadap obat-obatan yang ada, merupakan tantangan bagi industri farmasi dalam menyediakan produk antibiotik. Terbatasnya jumlah antibiotik merupakan masalah serius dalam pengobatan penyakit infeksi yang diakibatkan oleh meningkatnya resistensi bakteri patogen terhadap antibiotik yang tersedia. Penggunaan antibiotik yang tidak tepat dan tidak terkontrol telah mengakselerasi timbulnya strain bakteri yang bersifat resisten terhadap antibiotik yang biasa disebut MDR (multi drug resistance) (Abbanat dkk., 2003). Kecemasan yang muncul dalam penanganan penyakit infeksi akibat strain MDR mendorong berbagai penelitian untuk mengeksplorasi mikroba khususnya Actinomycetes yang menghasilkan senyawa antibiotik baru (Subramani \& Aalbersberg, 2013). Berdasarkan data penelitian menunjukkan kematian akibat penyakit infeksi masih relatif tinggi. Setiap tahun penyakit infeksi dapat menyebabkan kematian sekitar 3,5 juta orang (WHO, 2014).

Resistensi mikroba terhadap senyawa antibakteri selain menyebabkan kegagalan pengobatan juga meningkatkan biaya pengobatan. Kegagalan pengobatan akibat resistensi tidak dapat diatasi dengan menaikkan dosis obat tetapi harus ISSN-P : 1978-6417; ISSN-E : 2580-5991 dilakukan penggantian obat. Salah satu pendekatan yang dapat dilakukan adalah mencari antibakteri yang lebih efektif dari antibakteri yang ada melalui sintesis atau isolasi dari sumber alami yang potensial (Allen \& Nicas, 2003; Khaliq dkk., 2013). Antimikroba yang berasal dari alam tetap menjadi sumber yang menjanjikan untuk mendapatkan struktur antibiotik yang baru, meskipun perlu pendekatan baru untuk mendapatkan isolat-isolat mikroba, khususnya dari rhizosfer (Barreto dkk., 2008; Sembiring, 2009; Zhao dkk., 2012; Trabelsi dkk., 2016; Kumar dkk., 2017; Das dkk., 2018)).

Actinomycetes merupakan mikroba tanah (rhizosfer) yang banyak dikaji potensinya karena memiliki nilai ekonomi yang tinggi, diantaranya sebagai penghasil antibiotik (antibakteri), antifungi, antivirus, kemoterapeutik (agen antikanker), enzim, dan imunosupresan (Raja \& Prabakarana, 2011; Rajeswari dkk., 2015; Lima dkk., 2017). Barakate dkk. (2002) dan Oskay dkk. (2004) menyatakan bahwa semua antibiotik yang telah ditemukan, dua per tiganya dihasilkan oleh Actinomycetes.

Sumber mikroba yang penting untuk dieksplorasi adalah tanah hutan tropis khususnya daerah rhizosfer karena memiliki keragaman mikroba yang tinggi (Hartmann dkk., 2008). Hal ini berkaitan dengan kandungan sejumlah senyawa yang dapat bertindak sebagai substrat pertumbuhan mikroba. Selain kandungan 
hara yang cukup tinggi, di daerah rhizosfer juga terbentuk pola interaksi dengan mikroba yang hidup di sekitarnya, karena adanya metabolit sekunder yang dikeluarkan oleh tumbuhan (Hasegawa dkk., 2006). Dengan demikian terbentuk pula pola interaksi antara mikroba dengan tumbuhan dan mikroba dengan mikroba (Braga dkk., 2016). Kemampuan mengembangkan mekanisme kompetisi seperti mensintesis metabolit sekunder berupa antimikroba yang beragam dan unik menjadikan tempat ini memiliki beragam Actinomycetes (Tiwari \& Gupta, 2012; Zhao dkk., 2012).

Indonesia terletak di kawasan tropis dan memiliki keragaman hayati yang tinggi, maka berpeluang memperoleh Actinomycetes yang baru. Salah satu wilayah di Indonesia yang potensial ialah Taman Nasional Lore Lindu (salah satu lokasi perlindungan hayati Sulawesi), luasnya 217.991,98 ha. Taman nasional tersebut memiliki kelembaban rata-rata 98 $\%$, kelimpahan zat hara, $\mathrm{pH}$, dan suhu 2234 oC, curah hujan rata-rata 2.000-4.000 mm/tahun (Balai Besar TNLL, 2011) sehingga sangat cocok bagi kelangsungan hidup serta mendukung berbagai aktivitas mikroba termasuk Actinomycetes .

Penelitian tentang eksplorasi Actinomycetes penghasil antibakteri di Indonesia masih sangat terbatas, utamanya di TNLL masih belum ada, padahal mempunyai keragaman hayati yang melimpah (termasuk Actinomycetes).
Tumbuhan khas atau endemik pada suatu ekosistem sangat potensial sebagai sumber untuk memperoleh Actinomycetes. Bakteri ini mampu berasosiasi dengan tumbuhan untuk menghasilkan senyawa-senyawa antibiotik yang bermanfaat bagi dunia kesehatan (van der Meij dkk., 2017). Tumbuhan Eucalyptus deglupta Blume. merupakan tumbuhan endemik di TNLL yang potensial sebagai sumber yang baru untuk mengisolasi Actinomycetes penghasil senyawa antibakteri patogen pada manusia. Hasil penelitian menyatakan bahwa persenyawaan yang dihasilkan oleh Eucalyptus pada umumnya berbentuk volatil sebagai antibiotik dan antiseptik. Senyawa yang dihasilkan berasal dari asosiasi antara mikroba (fungi) dengan tumbuhan Eucalyptus (Kharwar dkk., 2010). Oleh sebab itu, diperlukan eksplorasi untuk mendapatkan Actinomycetes dari rhizosfer di Taman Nasional Lore Lindu guna mendapatkan senyawa-senyawa antibakteri yang bermanfaat di dunia kesehatan.

\section{BAHAN DAN METODE}

Penelitian ini dibagi dalam beberapa tahapan yakni: tahap sampling, isolasi, dan skrining Actinomycetes penghasil senyawa antibakteri, tahap uji efikasi senyawa antibakteri, dan tahap identifikasi morfologi dan pewarnaan isolat yang potensial menghasilkan senyawa antibakteri patogen. 
Sampel tanah rhizosfer tumbuhan Leda (Eucalyptus deglupta Blume.) diambil dari daerah Anaso-Rorekatimbu (Kamarora), Kawasan Pengelolaan II Makmur TNLL dengan 10 spot daerah penelitian. Daerah ini berada pada Zona Inti (core) yang terletak pada $1^{\circ} 12^{\prime}-1^{\circ} 22^{\prime}$ LS dan $120^{\circ} 05^{\prime}$ $-120^{\circ} 14^{\prime}$ BT.

\section{Pengambilan sampel tanah rhizosfer}

Metode sampling yang digunakan dalam penelitian ini adalah Purposive Sampling yang dipadukan dengan metode kuadran. Tanah diambil dari daerah perakaran menggunakan bor besi pada kedalaman $20 \mathrm{~cm}$ dari daerah perakaran tumbuhan (Varghese dkk., 2012; Khandan \& Janardhana, 2015; Das dkk., 2019). Sampel tanah rhizosfer yang diambil dari setiap pohon yang berada pada kuadran sebanyak 200 gram dan dianggap sebagai ulangan dan masing-masing ulangan merupakan komposit dari empat kali pengambilan sampel. Sampel tanah dimasukkan ke dalam plastik polietilen steril dan disimpan di kotak isotermis. Bersamaan dengan pengambilan sampel tanah rhizosfer dilakukan juga pengukuran parameter lingkungan. Parameter lingkungan tanah yang diukur secara langsung meliputi ketinggian tempat dari permukaan laut, intensitas cahaya di permukaan tanah, suhu tanah, kelembaban udara, dan titik koordinat yang ditentukan dengan menggunakan alat Global Positioning System (GPS).
Parameter tanah yang diukur di laboratorium meliputi keasaman tanah $(\mathrm{pH})$, serta kandungan karbon dan nitrogen organik (rasio $\mathrm{C} / \mathrm{N}$ ) tanah. Selain itu dicatat pula diameter pohon, tinggi pohon, dan jarak antarpohon.

\section{Isolasi dan skrining Actinomycetes}

Sampel tanah rhizosfer sebanyak 25 gram disuspensikan ke dalam $225 \mathrm{~mL}$ larutan garam fisiologis $(\mathrm{NaCl} \quad 0,9 \%)$ steril. Suspensi tanah dipanaskan di dalam waterbath pada suhu $70{ }^{\circ} \mathrm{C}$ selama satu jam sebagai skrining primer, kemudian dihomogenkan dengan rotary shaker selama 30 menit (Chaouch dkk., 2018). Suspensi tanah satu mililiter diencerkan dengan sembilan mililiter larutan garam fisiologis, selanjutnya diencerkan secara bertingkat sampai pengenceran $10^{-6}$. Suspensi sampel sebanyak $0,1 \mathrm{~mL}$ disebar ke dalam Cawan Petri steril yang berisi media isolasi Actinomycetes Starch Casein Agar (SCA) yang telah ditambahkan antibiotik nystatin (25 $\mu \mathrm{g} / \mathrm{mL})$, sikloheksamid $(50 \mu \mathrm{g} / \mathrm{mL})$ (Coombs \& Franco, 2003; Zhang dkk., 2012); (Alwi dkk., 2019), dan rifampisin (25 $\mu \mathrm{g} / \mathrm{mL}$ ) (Kumar dkk., 2010; Shetty dkk., 2014; Nguyen \& Kim, 2015). Cawan agar diinkubasi pada suhu $28^{\circ} \mathrm{C}$ selama tujuh hari dalam kondisi tanpa cahaya (Pandey dkk., 2011; Hong-Thao dkk., 2016). Jumlah Actinomycetes yang tumbuh dihitung dari setiap ulangan sampel. Data jumlah Actinomycetes yang 
tumbuh dihitung dan dianalisis untuk penentuan densitas Actinomycetes pada setiap spot lokasi penelitian. Korelasi berbagai parameter lingkungan terhadap densitas Actinomycetes dianalisis dengan Korelasi-Pearson menggunakan Program SPSS versi 24,0.

Koloni Actinomycetes yang morfologinya berbeda diseleksi dan dimurnikan secara berulang-ulang dengan metode gores kuadran sampai diperoleh koloni tunggal pada media SCA. Isolat Actinomycetes yang murni disimpan dalam media agar miring pada tabung reaksi untuk uji selanjutnya.

Skrining sekunder Actinomycetes yang terpilih sebagai penghasil antibakteri patogen pada manusia dilakukan uji antagonis dengan metode Agar Blocks (Nedialkova \& Naidenova, 2005; Sharma dkk., 2011; Muharram dkk., 2013; HongThao, 2016); (Alwi dkk., 2019). Semua Actinomycetes yang terpilih ditumbuhkan pada medium SCA selama delapan hari sampai membentuk spora. Lempeng kultur Actinomycetes dipotong dengan menggunakan cork-borer yang berdiameter lima milimeter dan diletakkan pada medium Nutrient Agar (NA) yang sebelumnya telah dinokulasikan secara spread plate bakteri uji sebanyak $0,1 \mathrm{~mL}$ dengan densitas sel $10^{6} \mathrm{sel} / \mathrm{ml}$. Bakteri uji yang digunakan adalah $S$. aureus, MRSA (Meticillin Resistant Staphylococcus aureus), EPEC (Enteropathogenic Escherichia coli), dan V. cholerae yang selanjutnya diinkubasi pada suhu $30{ }^{\circ} \mathrm{C}$ selama 48 jam dan diamati adanya daerah hambatan pertumbuhan. Data diameter zona hambat yang terbentuk pada masing-masing Actinomycetes dianalisis menggunakan Rancangan Acak Lengkap (RAL) dengan tiga kali ulangan. Data yang diperoleh dianalisis ragam dengan a $5 \%$ dan uji lanjut Tukey-HSD menggunakan Program SPSS versi 24.0.

\section{Karakterisasi Morfologi Actinomycetes} dari Rhizosfer Tumbuhan Leda

Morfologi Actinomycetes dikarakterisasi dengan mengamati pertumbuhan koloni di dalam tiga jenis media agar Starch Casein Agar (SCA), Medium Oatmeal Agar (ISP 3), dan Medium Tyrosine Agar (ISP 7). Kultur diinkubasi pada suhu $28^{\circ} \mathrm{C}$ selama 10 hari dan diamati warna, bentuk, elevasi, pinggiran, tekstur permukaan, dan warna di balik koloni; serta warna aerial hypha (miselium udara), vegetative hypha (miselium substrat) serta pigmen terdifusi. Morfologi isolat Actinomycetes dikarakterisasi secara mikroskopis dengan pewarnaan Gram dan metode slide culture (Tortora dkk., 2010). Actinomycetes dikultur di dalam media agar ISP3 dengan menggunakan metode slide culture untuk mengamati struktur miselia dan sporanya secara langsung menggunakan mikroskop perbesaran 500 - 1.000 kali. Morfologi isolat Actinomycetes yang telah diamati dibandingkan dengan morfologi Actinomycetes yang terdapat dalam 
Bergey's Manual untuk pendugaan identitas isolat sampai ke tingkat genus

\section{HASIL dan PEMBAHASAN}

Kondisi Lingkungan Tumbuhan Leda (Eucaplyptus deglupta Blume.) di Kawasan TNLL

Taman Nasional Lore Lindu (TNLL) yang terletak di Provinsi Sulawesi Tengah terdiri atas tiga Wilayah Kerja Resort Pengelolaan. Wilayah bagian barat dan selatan merupakan Pengelolaan Wilayah I Saluki yang berbatasan dengan Kabupaten Mamuju Utara (Provinsi Sulawesi Barat), Kabupaten Donggala, dan Kabupaten Luwu Utara (Provinsi Sulawesi Selatan). Wilayah bagian utara merupakan pengelolaan Wilayah II Makmur yang berbatasan dengan Kabupaten Sigi. Wilayah bagian timur merupakan pengelolaan Wilayah III Poso, yang berbatasan dengan Kabupaten Poso dan Kabupaten Parigi Moutong.

Lokasi tegakan tumbuhan Leda terletak di daerah Kamarora-Anaso Rorekatimbu yang termasuk dalam Wilayah Pengelolaan II Makmur. Secara geografi, Kamarora terletak pada $1^{\circ} 12^{\prime}$ - 1 $^{\circ} 16^{\prime}$ LS dan $120^{\circ} 05^{\prime}$ - $120^{\circ} 12^{\prime}$ BT. Secara umum kondisi faktor lingkungan di Wilayah Pengelolaan II Makmur adalah mirip yang dilaporkan oleh BPS Tahun 2016 di daerah Kabupaten Sigi. Kabupaten Sigi memiliki dua musim, sama dengan daerah-daerah lain di Indonesia, yaitu musim kemarau dan musim hujan. Musim kemarau terjadi antara Bulan April ISSN-P : 1978-6417; ISSN-E : 2580-5991
(Miyadoh \& Otoguro, 2004; Qin dkk., 2009).

September, sedangkan musim hujan terjadi pada Bulan Oktober - Maret. Suhu udara rata rata tertinggi terjadi pada Bulan Februari $\left(28,1{ }^{\circ} \mathrm{C}\right)$ dan suhu udara terendah terjadi pada Bulan Agustus (25,7 $\left.{ }^{\circ} \mathrm{C}\right)$. Kelembaban udara berkisar 75 - 93 $\%$. Kelembaban udara rata-rata tertinggi terjadi pada Bulan Agustus yang mencapai $93 \%$, sedangkan kelembaban udara rata-rata terendah terjadi pada Bulan Februari yaitu 75 \% (BPS, 2016).

Faktor lingkungan tegakan Leda yang diukur meliputi $\mathrm{pH}$ tanah, suhu tanah, kelembaban udara, intensitas cahaya, rasio $\mathrm{C} / \mathrm{N}$ tanah, ketinggian dari permukaan laut, tinggi pohon, diameter batang pohon, jarak antarpohon, dan densitas Actinomycetes. Lokasi tempat pengambilan sampel tanah rhizosfer tumbuhan Leda berada pada topografi ketinggian yang relatif menanjak. Kenampakan tekstur tanah rhizosfer pada umumnya adalah liat dan berwarna coklat muda. Secara umum tanah rhizosfer Leda mempunyai tingkat kemasaman mendekati $\mathrm{pH}$ netral $(\mathrm{pH} 7)$ (Tabel 1).

Rata-rata tinggi pohon Leda setiap spot tidak berbeda, karena jenis pohon ini adalah dilindungi dan tumbuh alami. Oleh karena itu vegetasinya tidak terganggu, dan jenis tumbuhan ini berhabitus perrenial dan pertumbuhannya lambat, serta tajuk dan perawakan tumbuhan ini 
hampir sama. Faktor $\mathrm{pH}$ tanah, rasio $\mathrm{C} / \mathrm{N}$ tanah, dan densitas Actinomycetes di setiap spot di kawasan ini relatif tidak berbeda $(p>0,05)$. Hal ini didukung oleh banyaknya dedaunan di lantai hutan yang diuraikan oleh mikroba dekomposer, termasuk Actinomycetes. Densitas Actinomycetes yang tinggi dapat menimbulkan perubahan rasio $\mathrm{C} / \mathrm{N}$ dan $\mathrm{pH}$ tanah (Barreto dkk., 2008). Hal ini pula yang menyebabkan keberadaan Actinomycetes lebih beragam dan densitasnya lebih tinggi di daerah rhizosfer dibandingkan dengan di luar rhizosfer (Hartmann dkk., 2008). Rata-rata densitas Actinomycetes yang ada di rhizosfer tumbuhan Leda di Rorekatimbu TNLL adalah $1,53 \times 10^{7}$ sel per gram tanah (Tabel 1).

Faktor lingkungan lainnya seperti intensitas cahaya, ketinggian tempat dari permukaan laut, kelembaban udara, suhu udara, dan suhu tanah dipengaruhi langsung oleh topografi kawasan tersebut. Kawasan tumbuhan Leda berada pada topografi daerah pegunungan Oleh karena itu faktor lingkungannya akan memengaruhi keberadaan mikroba khususnya jenis Actinomycetes-nya. Hal ini sesuai dengan yang dilaporkan Nurkamto dkk. (2010) yang mengatakan bahwa perbedaan topografi dan ketinggian tempat dari permukaan laut memengaruhi keberadaan jenis Actinomycetes yang hidup di dalamnya.

Tabel 1. Parameter lingkungan di kawasan tumbuhan Leda (Eucalyptus deglupta Blume.)

\begin{tabular}{clc}
\hline No. & \multicolumn{1}{c}{ Parameter } & Nilai Rata-Rata Pengukuran \\
\hline 1. & Diameter batang $(\mathrm{cm})$ & 88,40 \\
2. & Jarak antar pohon $(\mathrm{m})$ & 16,95 \\
3. & Tinggi pohon $(\mathrm{m})$ & 30,40 \\
4. & Ketinggian dpl. $(\mathrm{m})$ & $1.763,60$ \\
5. & Intensitas cahaya (lux) & 582,70 \\
6. & Kelembaban udara $(\%)$ & 90,60 \\
7. & Suhu udara $\left({ }^{\circ} \mathrm{C}\right)$ & 24,10 \\
8. & Suhu tanah $\left({ }^{\circ} \mathrm{C}\right)$ & 27,62 \\
9. & pH tanah (keasaman) & 6,78 \\
10. & Rasio C/N tanah & 11,59 \\
11. & Densitas Actinomycetes (sel/g) & \\
\hline
\end{tabular}

Karakteristik kimia tanah seperti $\mathrm{pH}$ tanah dan rasio $\mathrm{C} / \mathrm{N}$ tanah sangat ditentukan oleh keberadaan Actinomycetes di kawasan tersebut. Aktivitas Actinomycetes meningkatkan proses dekomposisi bahan organik, yang mengakibatkan C-organik berkurang dan N-total mengalami peningkatan. Akibatnya terjadi penurunan rasio $\mathrm{C} / \mathrm{N}$ yang menandakan terjadinya ISSN-P : 1978-6417; ISSN-E : 2580-5991 proses mineralisasi. Oleh karena itu rasio $\mathrm{C} / \mathrm{N}$ yang rendah, yakni kurang dari 20 menunjukkan bahwa proses mineralisasi berjalan dengan baik (Pratiwi dkk., 2013). Rasio C/N pada tegakan rhizosfer tumbuhan Leda kurang dari 20 yakni 11,59 (Tabel 1). Hal ini menunjukkan bahwa kawasan tersebut telah mengalami proses mineralisasi atau pengomposan 
bahan organik oleh mikroba. Dengan demikian peran serta Actinomycetes dalam pendegradasian bahan organik yang ada di lantai hutan pada tegakan Leda yang ada di Rorekatimbu berjalan dengan baik.

\section{Hubungan Faktor Lingkungan Tanah dengan Densitas Actinomycetes pada Rhizosfer Tumbuhan Leda}

Hasil penghitungan total plate count (TPC) dari 10 spot pengambilan sampel tanah rhizosfer tumbuhan Leda (Eucaplyptus deglupta Blume.) memenuhi syarat keberadaan jumlah Actinomycetes di daerah perakaran tumbuhan pada umumnya, yakni $10^{6}$ sampai dengan $10^{7}$ sel/gram tanah rhizosfer. Hal ini selaras dengan Sylvia dkk. (2005) dan Barreto dkk. (2008) yang menyatakan bahwa Actinomycetes adalah kelompok bakteri paling dominan yang mencapai populasi $10^{6}-10^{7} \mathrm{sel} / \mathrm{gram}$ tanah pada daerah rhizosfer. Dari 10 spot lokasi pengambilan sampel tanah rhizosfer tersebut maka spot ke-7 dan 8 paling banyak jumlah Actinomycetesnya mencapai $10^{7} \mathrm{sel} / \mathrm{gram}$ tanah rhizosfer, namun secara umum bahwa rata-rata densitas Actinomycetes di rhizosfer Leda adalah $1,53 \times 10^{7} \mathrm{sel} / \mathrm{gram}$ tanah. Hal ini didukung oleh beberapa faktor lingkungan yang memengaruhi keberadaan Actinomycetes di daerah rhizosfer tumbuhan Leda, yakni diameter batang tumbuhan Leda dan rasio $\mathrm{C} / \mathrm{N}$ tanah. Hal ini menandakan bahwa semakin besar diameter batang Leda maka semakin banyak pula jumlah Actinomycetesnya, sejalan dengan rasio $\mathrm{C} / \mathrm{N}$ yang semakin tinggi nilainnya maka jumlah Actinomycetes semakin banyak pula. Di alam utamanya habitat hutan tropis, makin besar diameter batang tumbuhan maka makin banyak menyumbangkan serasah ke lantai hutan sehingga dapat menaikkan nilai rasio $\mathrm{C} / \mathrm{N}$ tanah. Namun tingginya intensitas cahaya yang masuk menerangi lantai hutan dapat menurunkan densitas Actinomycetes pada tegakan hutan Leda tersebut (Tabel 2).

Tabel 2. Hubungan faktor lingkungan terhadap densitas Actinomycetes pada rhizosfer tumbuhan Leda dan Ebony

\begin{tabular}{|c|c|c|}
\hline \multirow{2}{*}{ Parameter } & \multicolumn{2}{|c|}{ Rhizosfer Leda } \\
\hline & r-hitung & $p$-value \\
\hline Diameter batang $(\mathrm{cm})$ & $0,457^{\mathrm{c}}$ & 0,043 \\
\hline Jarak antarpohon (m) & $-0,057$ & 0,812 \\
\hline Tinggi pohon $(m)$ & 0,311 & 0,182 \\
\hline Ketinggian dpl. (m) & 0,429 & 0,059 \\
\hline Intensitas cahaya (lux) & $-0,498^{c}$ & 0,025 \\
\hline Kelembaban udara (\%) & 0,423 & 0,063 \\
\hline Suhu tanah $\left({ }^{\circ} \mathrm{C}\right)$ & 0,161 & 0,498 \\
\hline $\mathrm{pH}$ tanah (kemasaman) & $-0,080$ & 0,737 \\
\hline Rasio $\mathrm{C} / \mathrm{N}$ & $0,476^{c}$ & 0,034 \\
\hline
\end{tabular}


Keterangan: notasi (c) pada setiap parameter menunjukkan ada korelasi $(p<0,05)$; nilai positif $r$-hitung (korelasi positif); nilai negatif $r$-hitung (korelasi negatif)

Pada kenyataannya spot tujuh dan delapan rata-rata lantai hutannya berserasah tebal dibandingkan dengan spot yang lain. Hal ini didukung oleh diameter batang tumbuhan Leda $37,74 \mathrm{~cm}$ (spot-7) dan 33,92 cm (spot-8) yang lebih besar dibandingkan dengan spot yang lain. Oleh karena itu diduga bahwa keberadaan Actinomycetes di daerah rhizosfer tumbuhan Leda dipengaruhi oleh banyaknya serasah yang dihasilkan oleh pohon Leda tersebut.

Demikian pula semakin tinggi nilai rasio $\mathrm{C} / \mathrm{N}$ tanah maka semakin banyak jumlah Actinomycetes yang ditemukan. Pada spot-7 dengan nilai rasio $\mathrm{C} / \mathrm{N} 14,85$ dan spot-8 dengan nilai 14,66 , rata-rata jumlah Actinomycetes yang ditemukan mencapai $10^{7} \mathrm{sel} / \mathrm{gram}$ tanah rhizosfer. Berdasarkan analisis korelasi Pearson menunjukkan bahwa semakin besar diameter batang tumbuhan Leda meningkatkan jumlah Actinomycetes. Demikian juga semakin tinggi rasio $\mathrm{C} / \mathrm{N}$ maka jumlah Actinomycetes semakin banyak. Hal ini dibuktikan dengan banyaknya serasah yang dihasilkan oleh pohon Leda yang berdiameter batang besar dibandingkan dengan pohon diameter kecil. Serasah merupakan penyumbang sumber karbon pada lantai hutan. Banyaknya sumber $\mathrm{C}$ dari serasah mengakibatkan rasio $\mathrm{C} / \mathrm{N}$ menjadi tinggi, akibatnya densitas Actinomycetes akan meningkat pula.
Parameter lingkungan lain seperti kelembaban udara, suhu tanah, $\mathrm{pH}$ tanah, ketinggian tempat dari permukaan laut, serta tinggi pohon tidak memengaruhi densitas Actinomycetes rhizosfer tumbuhan Leda di daerah AnasoRorekatimbu TNLL. Hal ini sejalan dengan hasil penelitian Nurkamto dkk (2012) yang menyatakan bahwa faktor ketinggian dari permukaan laut tidak memengaruhi keberadaan Actinomycetes yang ada di daerah Halmahera, Provinsi Maluku.

\section{Actinomycetes Rhizosfer Tumbuhan Leda Penghasil Antibakteri Patogen Manusia}

Actinomycetes yang diisolasi dari sampel tanah rhizosfer tumbuhan Leda (Eucalyptus deglupta Blume.) dari kawasan Taman Nasional Lore Lindu (TNLL) Sulawesi Tengah sebanyak 15 isolat. Actinomycetes tersebut merupakan penghasil antibakteri patogen pada manusia. Berdasarkan fenotip makroskopis dan mikroskopis, isolat-isolat Actinomycetes termasuk ke dalam kelompok Streptomyces atau Genus Streptomyces. Actinomycetes dari Genus Streptomyces ditandai dengan terbentuknya spora pada medium ISP3 (Gambar 1). Spora yang terbentuk berstruktur Arthrospora (Miyadoh \& Otoguro, 2004; Qin dkk., 2009). 
Semua isolat Actinomycetes tersebut telah diuji daya hambatnya terhadap beberapa bakteri patogen yang telah resisten seperti Staphylococcus aureus, MRSA, EPEC, dan Vibrio cholerae. Isolat L213 terlebar zona hambatnya terhadap $S$. aureus,
MRSA, dan EPEC $(\mathrm{p}<0,05)$, diikuti oleh isolat L433 dan L411. Isolat L213, L433, dan L411 memiliki zona hambat yang sama terhadap Vibrio cholerae namun berbeda dengan Actinomycetes lainnya (Tabel 3).

Tabel 3. Aktivitas isolat Actinomycetes rhizosfer tumbuhan Leda dalam menghambat pertumbuhan bakteri patogen manusia

\begin{tabular}{|c|c|c|c|c|c|}
\hline \multirow{2}{*}{ No. } & \multirow{2}{*}{$\begin{array}{c}\text { Kode isolat } \\
\text { Actinomycetes }\end{array}$} & \multicolumn{4}{|c|}{ Rata-rata $\varnothing$ zona hambat terhadap bakteri uji (mm) } \\
\hline & & S. aureus & MRSA & EPEC & V. cholerae \\
\hline 1 & L135 & $7,01^{\text {ab }}$ & $7,23^{\mathrm{bc}}$ & $6,14^{a}$ & $6,05^{a}$ \\
\hline 2 & L213 & $15,03^{f}$ & $18,48^{g}$ & $18,52^{g}$ & $8,99^{\mathrm{e}}$ \\
\hline 3 & L2310 & $8,16^{\text {de }}$ & $8,08^{\mathrm{cd}}$ & $7,11^{\mathrm{bc}}$ & $6,73^{a b}$ \\
\hline 4 & L249 & $7,45^{\mathrm{cd}}$ & $6,08^{a}$ & $6,03^{a}$ & $6,01^{\mathrm{a}}$ \\
\hline 5 & L312 & $6,10^{a}$ & $6,05^{\mathrm{a}}$ & $6,00^{a}$ & $6,04^{\mathrm{a}}$ \\
\hline 6 & L318 & $6,05^{a}$ & $6,04^{a}$ & $6,08^{a}$ & $6,02^{a}$ \\
\hline 7 & L411 & $8,45^{e}$ & $8,79^{e}$ & $9,18^{\mathrm{e}}$ & $9,57^{\mathrm{e}}$ \\
\hline 8 & L412 & $7,09^{a b}$ & $6,05^{a}$ & $6,13^{a}$ & $6,16^{a}$ \\
\hline 9 & L413 & $7,12^{\mathrm{bc}}$ & $7,03^{a b c}$ & $6,03^{a}$ & $6,13^{a}$ \\
\hline 10 & L427 & $7,13^{\mathrm{bc}}$ & $6,73^{a b}$ & $6,00^{a}$ & $6,02^{a}$ \\
\hline 11 & L428 & $7,33^{\mathrm{bc}}$ & $6,41^{a b}$ & $6,63^{a b}$ & $6,18^{a}$ \\
\hline 12 & L431 & $7,77^{\mathrm{cd}}$ & $6,00^{a}$ & $7,82^{\mathrm{cd}}$ & $8,27^{\text {de }}$ \\
\hline 13 & L432 & $7,66^{\mathrm{bc}}$ & $6,08^{a}$ & $7,32^{a b c}$ & $7,80^{\mathrm{cd}}$ \\
\hline 14 & L433 & $9,04^{e}$ & $9,18^{e}$ & $9,50^{e}$ & $9,73^{e}$ \\
\hline 15 & L526 & $6,45^{a b}$ & $6,02^{a}$ & $6,09^{a}$ & $6,03^{a}$ \\
\hline
\end{tabular}

Keterangan: Nilai yang diikuti oleh huruf yang berbeda pada kolom yang sama berbeda signifikan ( $p$ $\leq 0,05) ; \mathrm{n}=3$

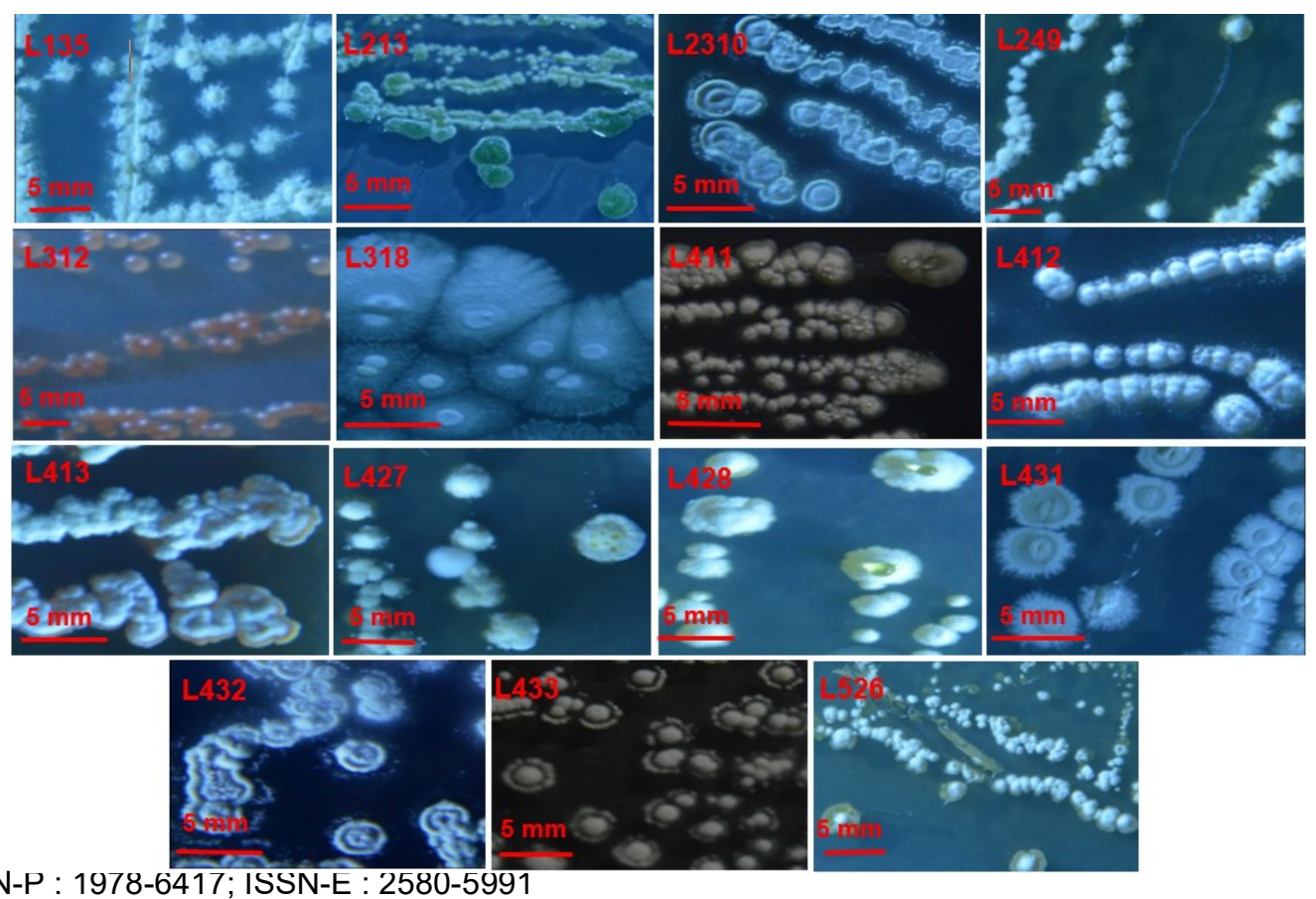


Gambar 1. Morfologi makroskopis Actinomycetes dari rhizosfer tumbuhan Leda

Adanya perbedaan aktivitas zona hambat Actinomycetes terhadap bakteri uji dipengaruhi oleh berbagai faktor. Selain faktor genetik, faktor lingkungan dan faktor biotik lainnya juga memengaruhi biosintesis metabolit sekunder yang dihasilkan oleh Actinomycetes. Biosintesis metabolit sekunder dalam bentuk senyawa bioaktif oleh Actinomycetes dipengaruhi oleh berbagai faktor lingkungan seperti suhu, cahaya, konsentrasi oksigen, sumber karbon dan nitrogen (Ruiz dkk., 2010). Kelimabelas isolat yang ditemukan mampu menghambat terhadap pertumbuhan bakteri patogen yang diberikan. Isolat L213, L433 dan L411 dari rhizosfer Leda memiliki kemampuan daya hambat yang paling baik terhadap bakteri uji.

Menurut Berdy (2005; 2012) metabolit sekunder pada tumbuhan sebenarnya disintesis oleh mikroba yang berasosiasi dengannya, atau kedua organisme ini berinteraksi menghasilkan senyawa bioakif secara bersama-sama. Oleh karena itu Actinomycetes yang berasosiasi dengan tumbuhan Leda diduga bersifat spesifik. Menurut Berdy (2005), Yilmaz dkk. (2008), dan Lanoue dkk. (2010) bahwa Actinomycetes dengan tumbuhan dalam suatu ekosistem keberadaaan saling memengaruhi. Tumbuhan mengekskresikan berbagai senyawa berupa gula, gula-alkohol, asam amino, dan asam organik sebagai sumber $C$ dan
$\mathrm{N}$ untuk Actinomycetes, sebaliknya Actinomycetes mengekskresikan berbagai senyawa untuk pertumbuhan tumbuhan. Actinomycetes setelah memasuki fase pertumbuhan idiofase (fase stasioner), maka metabolit sekunder disintesis. Pada periode ini sel Actinomycetes umumnya mensintesis senyawa-senyawa bioaktif (Cundliffe \& Demain, 2010). Sel Actinomycetes pada fase tersebut resisten terhadap senyawa-senyawa bioaktif, sehingga mampu bertahan hidup sampai periode ini berakhir. Hal tersebut disebabkan Actinomycetes mampu mensintesis antibiotik sebagai metabolit sekunder yang berpotensi autotoksik dan berfungsi untuk melindungi selnya secara keseluruhan.

\section{SIMPULAN}

Faktor lingkungan memengaruhi keberadaan Actinomycetes pada rhizosfer tumbuhan Eucalyptus deglupta Blume. yang ada di Rorekatimbu Taman Nasional Lore Lindu. Actinomycetes yang berhasil diisolasi dari rhizosfer tumbuhan Eucalyptus deglupta Blume. di TNLL Provinsi Sulawesi Tengah yang berpotensi sebagai antibakteri patogen sebanyak 15 isolat dan dinyatakan semuanya adalah Genus Streptomyces. Actinomycetes isolat L213, L433, dan L411 dari rhizosfer tumbuhan Leda paling tinggi potensinya sebagai antibakteri terhadap 
Staphylococcus aureus, MRSA, EPEC, dan Vibrio cholera.

\section{DAFTAR PUSTAKA}

Abbanat, D., Mucieleg, M., \& Bush, K. 2003. Novel antibacterial agents for the treatment of serious Grampositive infections. Expert. Opin. Inv. Drug. 12:379-399.

Allen, N.E. \& Nicas, T.I. 2003. Mechanism of action of oritavancin and related glycopeptides antibiotics. FEMS Microbiol. Rev. 26(5):511-532.

Alwi, M., Suharjono, S., Ardyati, T., \& Subandi, S. 2019. Antibacterial activities of Actinomycetes isolated from rhizosphere Diospyros celebica Bakh. In Lore Lindu National Park, Indonesia. Drug Inven. Today. 11(12):3400-3408.

Badan Pusat Statistik [BPS]. 2016. Sulawesi Tengah dalam Angka 2015. Badan Pusat Statistik Sulawesi Tengah, Palu.

Balai Besar Taman Nasional Lore Lindu [BBTNLL]. 2011. Statistik Taman Nasional Lore Lindu. Balai Besar TNLL. Sulawesi Tengah: Palu.

Barakate, M., Ouhdouch, Y., Oufdou, K.H., \& Beaulieu, C. 2002. Characterization of rhizosperic soil Streptomyces from Moroccan habitats and their antimicrobial activities. World J. Microbiol. Biot. 18:49-54.

Barreto, T.R., da Silva, A.C.M., Soares, A.C.F., \& de Souza, J.T. 2008. Population densities and genetic diversity of Actinomycetes associated to the rhizosphere of the Theobroma cacao. Brazilian J. Microbiol. 39:464-470.

Berdy, J. 2005. Bioactive microbial metabolites. J. Antibiotechnol. 58 (1):1-26.

Berdy, J. 2012. Thoughts and facts about antibiotics: Where we are now and where we are heading. J. Antibiotics. 65(8):385-395.

Braga, R.M., Dourado, M.N., \& Araujo, W.L. 2016. Microbial interactions: Ecology in a molecular perspective. Brazilian J. of Microbiol. 47:86-98.

Chaouch, F.C., Bouznada, K., Bouras, N., Meklat, A., Tata, S., Mokrane, S., Lamari, L., Florence, M., Sproer C., Klenk, H.P., \& Sabaou, N. 2018. Planomonospora, Saccharothrix and Actinophytocola genera in Saharan soils of Algeria: Isolation, taxonomic identification and antagonistic properties. J. Microbiol. Biotech. Food Sci. 7(5):505-510.

Coombs, J.T. \& Franco, C.M.M. 2003. Isolation and identification of Actinobacteria from surface-sterilized wheat roots. Appl. and Environ. Microbiol. 69(9): 5603-5608.

Cundliffe E. \& Demain A.L. 2010. Avoidance of suicide in antibioticproducing microbes. J. Indonesia Microbiol. Biotechnol. 37:643-672.

Das, R., Romi, W., Das, R., Sharma, HK., \& Thakur, D. 2019. Antimicrobial potentiality of actinobacteria isolated from two microbiologically unexplored forest ecosystems of Northeast India. BMC Microbiol. 71:01-16. 
Hartmann, A., Rothballe, M., \& Schmid, M. 2008. Lorenz Hiltner, a pioneer in rhizosphere microbial ecology and soil bacteriology research. Plant soil. 312:7-14.

Hasegawa, S., Meguro, A., Shimizu, M., Nishimura, T., \& Kunoh, H. 2006. Endophytic Actinomycetes and their interaction with host plants. Actinomycetologica 20(2):72-81.

Hong-Thao, P.T., Mai-Linh, N.V., HongLien, N.T., \& Hieu, N.V. 2016. Biological characteristics and antimicrobial activity of endophytic Streptomyces sp. TQR12-4 isolated from Elite Citrus nobilis cultivar Ham Yen of Vietnam. (Hindawi Pub.) Inter. J. of Microbiol. 2016:1-7.

Khaliq, S., Ghauri, M.A., \& Akhtar, K. 2013. Isolation, identification, and optimization of fermentation parameters for improved production of antimicrobial compounds from indigenous Streptomyces isolates. Afric. J. Microbiol. Research. 7(18):1874-1887.

Khandan, D.N., \& Janardhana, G.R. 2015. Isolation, identification and assessment of the antimicrobial activity of Streptomyces flavogriseus strain ACTK2 from soil sample from Kodagu, Karnataka State in India. Jundishapur J. Microbiol. 8:1-8.

Kharwar, R.N., Gond, S.K., Kumar, A., \& Mishra, A. 2010. A comparative study of endophytic and epiphytic fungal association with leaf of Eucalyptus citriodora Hook. and their antimicrobial activity. World $\mathrm{J}$. Microbiol. Biotechnol. 26:1941-1948.

Kumar, N., Singh, R.K., Mishra, S.K., Singh, A.K., \& Pachouri, U.C. 2010. ISSN-P : 1978-6417; ISSN-E : 2580-5991
Isolation and screening of soil Actinomycetes as source of antibiotics active against bacteria. International J. Microbiol. Research. 2(2): 12-16.

Kumar, PS., Paulraj, MG., Ignacimuthu, S., Al-Dhabi, NA., \& Sukumaran, D. 2017. In vitro antagonistic activity of soil Streptomyces collinus DPR20 against bacterial pathogens. $J$. Microbiol. Biotech. Food Sci. 7(3):317-324.

Lanoue, A., Burlat, V., \& Henkes, G.J. 2010. De novo biosynthesis of defense roots exudates in response to Fusarium attack in barley. New Phytol. 185:577-588.

Lima, S.M., Melo, J.G., Militao, G.C., Lima, G.M., do Carmo, A.L.M., Aquiar, J.S., Araujo, R.M., Braz-Filho, R., Marchand, P., Araujo, J.M., \& Silva, T.G. 2017. Characterization of the biochemical, physiological, and medicinal properties of Streptomyces hygroscopicus ACTMS-9H isolated from the Amazon/Brazil. Appl Microbiol. Biotechnol. 101:711-723.

Miyadoh, S. \& Otoguro, M. 2004. Workshop on Isolation Methods and Classification of Actinomycetes. Biotechnology Center-LIPI, Bogor.

Muharram, M.M., Abdelkader, M.S., \& Alqasoumi, S. 2013. Antimicrobial activity of soil Actinomycetes isolated from Alkharj, KSA. International Research J. of Microbiol. 4(1): 12-20.

Nedialkova \& Neidenova. 2005. Screening the antimicrobial activity of Actinomycetes strains isolated from Antarctica. J. Culture Collect. 4:2935. 
Nguyen, T.M. \& Kim, J. 2015. Streptomyces bambusae sp. nov., Showing antifungal and antibacterial activities, isolated from bamboo (Bambuseae) rhizosphere soil using a modified culture method. Curr Microbiol. 71:658-668.

Nurkamto, A., Listyaningsih, F., Julistiono, H., \& Agusta, A. 2010. Eksplorasi keanekaragaman Aktinomisetes tanah Ternate sebagai sumber antibiotik. J. Biol. Indonesia. 6(3):325-339.

Oskay, M., Tamer, U., \& Azeri, C. 2004. Antibacterial activity of some Actinomycetes isolated from farming soil of Turkey. African J. of Biotech. 3(9):441-446.

Pandey, A., Ali, I., Butola, K.S., Chatterji, T., \& Singh, V. 2011. Isolation and characterization of Actinomycetes from soil and evaluation of antibacterial activities of Actinomycetes againts pathogens. International J. Appl.Biol. and Pharmaceutic. Technol. 2(4):384392.

Pratiwi, I.G.A.P., Atmaja, I. W. D., \& Soniari, N.N. 2013. Analisis kualitas kompos limbah persawahan dengan mol sebagai dekomposer. J. Agroteknologi Tropika. 2(4):195-203.

Qin, S., Li, J., Chen, H.H., Zhao, G.Z., Zhu, W.Y., Jiang, C.L., Xu, L.H., \& Li, W.J. 2009. Isolation, diversity and antimicrobial activity of rare Actinomycetes from medicinal plants of tropical rain forests in Xishuangbanna, China. Appl. and Environ. Microbiol. 75(19):61766186.

Raja, A. \& Prabakara, P. 2011. Actinomycetes and drug an overview. American J. of Drug Disc \& Development. 1(2):75-84.

Rajeswari, P., Jose, P.A., Amiya, R., \& Jebakumar, S.R.D. 2015. Characterization of saltern based Streptomyces sp. and statistical media optimization for its improved antibacterial activity. Front Microbiol. 5/753:01-11.

Ruiz, B., Chaves, A., \& Forero, A. 2010. Production of microbial secondary metabolites: Regulation by the carbon source. Crit. Rev. Microbiol. 36:146-167.

Sembiring, L. 2009. Molecular phylogenetic classification of Streptomyces isolated from the rhizosphere of tropical legume Paraserianthes falcataria (L.) Nielsen. J. Bioscienc. Hayati 16(3):100-108.

Sharma, D., Kaur, T., Chadha, B.S., \& Manhas, R.J. 2011. Antimicrobial activity of Actinomycetes againts Multidrug Resistant Staphylococcus aureus, E. coli and various other pathogens. Trop. J. Pharm. Res. 10(6):801-808.

Shetty, P.R., Buddana, S.K., Tatipamula, V.B., Naga, Y.V.V., \& Ahmad, J. 2014. Production of polypeptide antibiotic from Streptomyces parvulus and its antibacterial activity. Brazilian J. of Microbiol. 45(1):303312.

Subramani, R. \& Aalbersberg, W. 2013. Culturable rare Actinomycetes: Diversity, isolation and marine natural product discovery. Appl. Microbiol. Biotechnol. 97:9291-9321. 
Sylvia, D.M., Fuhrmann, J.J., Hartel, P.G., \& Zuberer, D.A. 2005. Principles and Aplications of Soil Microbiology $\left(2^{\text {nd }}\right.$ eds.). Pearson Education Inc. Upper Saddle Rivers: New Jersey.

Tiwari, K. \& Gupta, R. K. 2012. Diversity and isolation of rare Actinomycetes: An Overview. Crit. Rev. Microbiol. 39:256-294.

Tortora, G.J., Funke, B.R., \& Case, C.L. 2010. Microbiology an Introduction (Tenth edition). Pearson Benjamin Cummings: San Francisco.

Trabelsi, I., Oves, D., Manteca, A., Ginelloud, O., Altahi, A., \& Nour, M. 2016. Antimicrobial activities of some Actinomycetes isolated from different rhizospheric soils in Tunisia. Curr Microbiol. 73:220-227.

van der Meij, A., Worsley, S.F., Hutchings, M.I., \& van Wesel, G.P. 2017. Chemical ecology of antibiotic production by Actinomycetes. FEM Microbiol. Rev. 41:392-416.

Varghese, R., Suchitrhra, R., Nishamol, S., \& Hatha, A.A.M. 2012. Spatiotemporal variation and antibacterial activity of Actinomycetes isolated from high altitude grassland soils of tropical montane Forest-Kerala, India. Studia Univ Vasile Goldis. 22:451-455.

World Health Organization [WHO]. 2014. Companion handbook to the WHO guidelines for the programmatic management of drug-resistant tuberculosis. WHO Document Production Service, Geneva, Switzerland.

Yilmaz, E.I., Yavuz, M., \& Kizil, M. 2008. Molecular characterization of rhizospheric soil Streptomycetes isolated from indigenous Turkish plants and their antimicrobial activity. World J. Microbiol. Biotechnol. 24:1461-1470.

Zhang, X., Ren, K., \& Zhang, L. 2012. Screening and preliminary identification of medicinal plants endophytic Actinomycetes used for inhibiting Penicillin-Resistant Staphylococcus aureus. Inter. J. of Biol. 4(2):119-124.

Zhao, K., Penttinen, P., Chen, Q., Guan, T., Lindstrom, K., Ao, X., Zhang, L., \& Zhang, X. 2012. The rhizospheres of traditional medicinal plants in Panxi, China, host a diverse selection of Actinobacteria with antimicrobial properties. Appl. Microbiol. Biotechnol. 94:1321-1335. 